\title{
High-pressure supercritical carbon dioxide uses to inactivate Escherichia coli in
}

\section{pumpkin puree}

\section{Uso de alta pressão com dióxido de carbono supercrítico para inativar Escherichia coli em purê de abóbora \\ Uso de alta presión con dióxido de carbono supercrítico para inactivar Escherichia coli en puré de}

Luís Carlos Oliveira dos Santos Júnior

ORCID: https://orcid.org/0000-0001-5532-502X Universidade Federal de Santa Catarina, Brazil E-mail: luisc.oliveirajr@gmail.com

Iuri Heberle

ORCID: https://orcid.org/0000-0001-9271-338X Universidade Federal de Santa Catarina, Brazil E-mail:iuribom@hotmail.com

Ana Carolina Moura de Sena Aquino ORCID: https://orcid.org/0000-0002-0832-5198 Universidade Federal de Santa Catarina, Brazil E-mail:ana.carolina@ifsc.edu.br José Vladimir Oliveira ORCID: https://orcid.org/0000-0002-6196-3498 Universidade Federal de Santa Catarina, Brazil E-mail: jvladimiroliveira@gmail.com Deise Helena Baggio Ribeiro ORCID: https://orcid.org/ 0000-0001-6023-9812 Universidade Federal de Santa Catarina, Brazil E-mail:deise.baggio@ufsc.br

João de Deus Medeiros ORCID: https://orcid.org/0000-0001-8208-5404 Universidade Federal de Santa Catarina, Brazil E-mail:jd.medeiros@ufsc.br Edna Regina Amante ORCID: https://orcid.org/0000-0001-9593-5674 Universidade Federal de Santa Catarina, Brazil E-mail:e.amante@ufsc.br

\begin{abstract}
E. Coli ATCC 25922 inactivation was studied to determine the effect of high-pressure carbon dioxide (HPCD) process on pumpkin puree. Experiments were performed using a batch HPCD system at three conditions of pressure (7.5 MPa, 17.5 MPa and 27.5 MPa) at $32{ }^{\circ} \mathrm{C}$. Afterwards, at the best experimental condition (27.5 MPa $-275 \mathrm{bar}$ ), a kinetic was performed to assess inactivation of microorganisms over time (from 1 to $8 \mathrm{~h}$ ). The physicochemical characteristics $(\mathrm{pH}$, total soluble solids - TSS, titratable acidity - TA, total carotenoids, total reducing sugars - TRS, moisture and optical microscopy) of the pumpkin puree were also evaluated. HPCD with acidification increases bacterial efficacy of treatments, as well as significant changes in physicochemical parameters. HPCD treatment reduced the microbial load moderately in all experiments, by a maximum of approximately $3.17 \log$ cycles in $8 \mathrm{~h}$ of process at $27.5 \mathrm{MPa}(275 \mathrm{bar})$. Optical microscopy showed no difference in cell wall, just in starch which was expected by cooking.
\end{abstract}

Keywords: E. coli; Pumpkin puree; Supercritical technology; Physicochemical characteristics; Optical microscopy.

\section{Resumo}

A inativação da $E$. coli ATCC 25922 foi estudada para determinar o efeito do processo de alta pressão com dióxido de carbono (HPCD) em purê de abóbora. Os experimentos foram realizados utilizando um sistema em batelada de HPCD em três condições de pressão $(7,5 \mathrm{Mpa}, 17,5 \mathrm{Mpa}$ e $27,5 \mathrm{Mpa})$ a $32^{\circ} \mathrm{C}$. Depois, na melhor condição experimental (27,5 Mpa - 275 bar), uma cinética foi realizada para avaliar a inativação de micro-organismos ao longo do tempo (de 1 a $8 \mathrm{~h}$ ). As características físico-químicas ( $\mathrm{pH}$, sólidos solúveis totais - TSS, acidez titulável - TA, carotenoides totais, açúcares redutores totais - TRS, umidade e microscopia óptica) do purê de abóbora foram também avaliadas. 
HPCD com acidificação aumentou a eficácia bacteriana dos tratamentos, bem como mudanças significativas nos parâmetros físico-químicos. O tratamento com HPCD reduziu a carga microbiana de forma moderada em todos os experimentos para um máximo de até 3,17 ciclos log em 8 h de processos a 27,5 Mpa (275 bar). A microscopia óptica mostrou que não houve diferença na parede celular, apenas nas estruturas do amido, o que era esperado pela ação do cozimento.

Palavras-chave: E. coli; Purê de abóbora; Tecnologia supercrítica; Características físico-químicas; Microscopia óptica.

\section{Resumen}

La inactivación de E. coli ATCC 25922 se estudió para determinar el efecto del proceso de alta presión con dióxido de carbono (HPCD) sobre el puré de calabaza. Los experimentos se llevaron a cabo utilizando un sistema discontinuo de HPCD en tres condiciones de presión (7,5 MPa, 17,5 MPa y 27,5 MPa) a $32{ }^{\circ} \mathrm{C}$. Luego, en la mejor condición experimentale (27.5 Mpa - 275 bar), se realizó una cinética para evaluar la inactivación de microorganismos a lo largo del tiempo (de 1 a 8 h). También se evaluaron las características fisicoquímicas (pH, sólidos solubles totales - TSS, acidez titulable - TA, carotenoides totales, azúcares reductores totales - TRS, humedad y microscopía óptica). El HPCD con acidificación aumentó la eficacia bacteriana de los tratamientos, así como cambios significativos en los parámetros físico-químicos. El tratamiento con HPCD redujo la carga microbiana de forma moderada en todos los experimentos hasta un máximo de 3,17 ciclos logarítmicos en 8 h de procesos a 27,5 MPa (275 bar). La microscopía óptica mostró que no había diferencia en la pared celular, solo en las estructuras del almidón, lo que se esperaba por la acción de cocción.

Palabras clave: E. coli; Puré de calabaza; Tecnología supercrítica; Características físico-químicas; Microscopía óptica.

\section{Introduction}

Pumpkin puree is a raw material with $\mathrm{pH}$ in the range of risk for pathogenic microorganisms (> 4.5) (Satiro et al., 2020), as well as availability of nutrients, particularly soluble carbohydrates, contrast with the practical prospects of pumpkin puree, for example, requiring additional care (Jay, 2005).

Non-thermal processing techniques, such as high pressure carbon dioxide (HPCD) with supercritical $\mathrm{CO}_{2}$ may be applied to control spoilage or pathogenic bacteria with minor loss of nutrients content.

Pressurized $\mathrm{CO}_{2}$ has the ability to diffuse through solids and dissolve materials resulting in bactericidal action. In addition, $\mathrm{CO}_{2}$ has several potential benefits, since it is not flammable, chemically inert, non-toxic, can be easily obtained with high purity, plenty available at relatively low cost when compared to other gases, low critical temperature ( $\left.31.1^{\circ} \mathrm{C}\right)$. The low critical temperature of $\mathrm{CO}_{2}$ is slightly above room temperature, so thermal degradations are not a problem when a process is operated around the critical temperature (Reid et al., 1985; Spilimbergo et al., 2003; Garcia-Gonzalez et al., 2007; Furukawa et al., 2009; Garcia-Gonzalez et al., 2009; Ferrentino \& Spilimbergo, 2011; Silva et al., 2013).

The inhibition of microbial growth by $\mathrm{CO}_{2}$ is not yet fully understood, as well as the way that the inactivation of microorganisms occurs. According to Garcia-Gonzalez et al. (2007), which gathered several works of literature to better understand the microbial inactivation mechanism by treatment with HPCD, some hypotheses have been listed: solubilisation of the pressurized $\mathrm{CO}_{2}$ in the external liquid phase; changes in cell membrane; decrease in extracellular pH; inactivation of key enzymes or inhibition in cellular metabolism as a function of decreasing of $\mathrm{pH}$; inhibitory effect of $\mathrm{CO}_{2}$ and $\mathrm{HCO}_{3}^{-}$in metabolism; disorder of electrolytes intracellular balance; removing vital components of cell and cell membrane. Spilimbergo et al. (2003) reported that the biocidal effects of HPCD on pathogens bacteria in foods are due to: explosion of wall cell as a function of the internal pressure; modification of cell membrane and extraction of lipids from the cell wall; inactivation of enzymes essential for microbial metabolism; extraction of intracellular compounds.

Moreover, different factors affect the inactivation of microorganisms by HPCD. Among the main ones, are the following: temperature, pressure, depressurizing rate, number of pressurization cycles, process time, ratio between $\mathrm{CO}_{2}$ and product, initial population of microorganisms, microbial growth phase and medium (Garcia-Gonzalez et al., 2007; Furukawa et al., 2009; Garcia-Gonzalez et al., 2009; Ferrentino \& Spilimbergo, 2011; Silva et al., 2013). 
Pumpkin processing studies are scarcer than other fruits and typically use thermal processing. In this context, the main objective of this work is to investigate the effects of HPCD to inactivate E. coli in pumpkin puree and its physicochemical and microstructure.

\section{Methodology}

\subsection{Raw material}

Pumpkins of "menina brasileira" variety (Cucurbita moschata) were obtained from a commercial establishment of Florianópolis - SC (Brazil), farmed in Angelina, Santa Catarina (Brazil).

\subsection{Production of pumpkin puree}

The pumpkins were cleaned with a neutral detergent and washed to remove surface dirt. The samples were cut into slices and then boiled for $20 \mathrm{~min}$ to soft tissue. The pieces were cooled and peeled and the seeds were removed. The puree was prepared through manual smashing with a fork. The puree was portioned and $30 \mathrm{~g}$ were placed in glass bottles with screw caps and sterilized by autoclaving at $121^{\circ} \mathrm{C}$ for $15 \mathrm{~min}$ to remove microbial load. After autoclaving process, the bottles were stored in a domestic refrigerator at $4{ }^{\circ} \mathrm{C}$.

\subsection{Characterization of pumpkin puree}

Physicochemical analyses were performed on samples of fresh pumpkins (in natura), as well on purees before (Puree) and after being sterilized (S puree) and after being subjected to HPCD (S puree + HPCD). The physicochemical analyses were pH-value, total soluble solids (TSS), titratable acidity (TA), total reducing sugars (TRS) and total carotenoids.

The $\mathrm{pH}$ was determined with a $\mathrm{pH}$ meter (Quimis, Diadema, Brazil). The TSS were measured at room temperature using a tropenmodell I refractometer (Carl Zeiss, Jena, Germany) and expressed as ${ }^{\circ}$ Brix ( $\mathrm{g}$ sucrose per $100 \mathrm{~g}-\mathrm{on}$ a fresh basis). To determinate TA, the purees were diluted in water $(1: 50 \mathrm{v} / \mathrm{v})$ and the mixture was titrated with $0.1 \mathrm{~mol} \mathrm{~L}^{-1} \mathrm{NaOH}$ in the presence of phenolphthalein. The TRS was determined using a spectrophotometric method of 3,5 dinitrosalicylic acid (DNS) (Miller, 1959).

To determine the total carotenoids, the method proposed by Kimura and Rodriguez-Amaya (2002) was adopted, with modifications in terms of weight and volume of samples and reagents. The absorbance was determined at $450 \mathrm{~nm}$ (U-1800 Hitachi, Tokyo, Japan) (Kimura et al., 2007). The total carotenoid content $\left(\mu \mathrm{g} \mathrm{g}^{-1}\right)$ was calculated by using the absorption coefficient of $\beta$-carotene in petroleum ether.

\subsection{Inoculum preparation}

The microorganism E. coli (ATCC 25922) was subcultured in BHI broth at $37{ }^{\circ} \mathrm{C}$ for $24 \mathrm{~h}$. The cultures used in all experiments were freshly prepared by the same procedure. The final number of $E$. coli was about of $10^{8}$ colony forming units (CFU) per $\mathrm{mL}$.

\subsection{Experimental apparatus and procedure}

The sterilized puree and non-sterilized puree (to physicochemical analyses) samples were submitted to HPCD using supercritical $\mathrm{CO}_{2}$ as a solvent. Each sample in the sterile bottle was inoculated with $100 \mu \mathrm{L}$ of E. coli, reaching a total count around $10^{8} \mathrm{CFU}$. Inactivation experiments were conducted employing the static-synthetic method in a high-pressure variablevolume view cell, schematically presented by Silva et al. (2013). Briefly, the experimental set-up consists of a variable-volume view cell, with a maximum internal volume of $27 \mathrm{~mL}$, with two sapphire windows for visual observation, an absolute pressure 
transducer (Smar, LD 301), with a precision of $\pm 0.03 \mathrm{MPa}$, a portable programmer (Smar, HT 201) for the pressure data acquisition and a syringe pump (ISCO 260D). The inactivation cell contains a movable piston, which permits the pressure control inside the cell. Initially, about $10 \mathrm{~mL}$ were loaded into the inactivation cell.

The charge of $\mathrm{CO}_{2}$ was performed with the syringe pump (resulting in an accuracy of $\pm 0.005 \mathrm{~g}$ in $\mathrm{CO}_{2}$ loadings). The mass of cell suspension and $\mathrm{CO}_{2}$ were based on the experimental design. With known values of pressure and temperature in the syringe pump reservoir, solvent density was estimated using the HBT (P-V-T) correlation for compressed liquids (Reid et al., 1985). The cell was kept at $32^{\circ} \mathrm{C}$.

The system pressure was increased using $\mathrm{CO}_{2}$ as pressurizing fluid from its vapour pressure at room (laboratory) temperature ( $\pm 5 \mathrm{MPa}$ ) up to the pressure established in the experimental design (initial working pressure) at a pressurization rate of $10 \mathrm{MPa} \mathrm{min}^{-1}$. At this point, the system was held for a certain short period to allow system stabilization, and then the pressure was decreased to $\mathrm{CO}_{2}$ vapour pressure at the predetermined depressurization rate. Initially, the treatment time for all runs was kept at $2 \mathrm{~h}$, for the experimental design.

At first, it was carried out an experimental $3^{2}$ design with triplicate central points to assess the best treatment condition (Pressure of 75, 175 and 275 bar) and Ratio $\mathrm{v}_{\text {pumpkin puree }} \mathrm{v}_{\mathrm{CO} 2}$ (wt \%) of 1:0.5; 1:0.75 and 1:1. The mass of sample was set in approximately $10 \mathrm{~g}$ while the $\mathrm{CO}_{2}$ ratios ranged. It was found the pressure condition in which there was a greater reduction in the number of microorganisms. This condition was selected to perform inactivation kinetics with a maximum time of $8 \mathrm{~h}$, all in triplicate, always observing the tendency of the linearization curve.

\subsection{Microbiological analysis}

The standard plate count technique was used to determine the initial microbial concentration and the efficiency of the treatment in reducing the number of the microorganisms. For inoculation, $100 \mu \mathrm{L}$ of culture were added to each sample $(25 \mathrm{~g})$ and thoroughly mixed for $3 \mathrm{~min}$ with a sterile spoon to ensure even distribution of the microorganism. The inoculated samples were stored at $37^{\circ} \mathrm{C}$ for $1 \mathrm{~h}$ until being plated for the initial count and approximately $3 \mathrm{~h}$ (kept cool) until HPCD treatment.

Uniform distribution of inoculum was confirmed by similar log CFU counts ( $\log 5-6 \mathrm{CFU} / \mathrm{g}$ ) on Petrifilm ${ }^{\mathrm{TM}}$ (3M Microbiology Products Co., St. Paul, MN) selective for E. coli/coliforms. A one-millilitre sample was aseptically transferred to the centre of the Petrifilm ${ }^{\mathrm{TM}}$ agar surface. Peptone water (PW) $0.1 \%$ (1:9) was added to the individual HPCD-treated samples and controls. Then, the sample and $0.1 \%$ PW mixture was homogenized for 1 min by a shaking flask. The homogenate (1.0 $\mathrm{mL}$ aliquots), after serially diluted (decimal dilutions), was plated on E. coli/coliform Petrifilm ${ }^{\mathrm{TM}}$. Films were stacked and incubated horizontally, free of any possible interference that could affect the results or interact with the homogenate, at $37{ }^{\circ} \mathrm{C}$ for 24h. Following the incubation, the colonies were counted, with blue to blue-red colonies with entrapped gas scored as $E$. coli and converted to logarithms (base 10) of colonies forming units per g ( $\log _{10} \mathrm{CFU} / \mathrm{g}$ ).

The inactivation degree after HPCD treatment was determined by evaluating the $\log (N)$ versus time, where $N$ (CFU/g, colony forming unit per gram) is the number of survivors after treatment. Three independent experiments were carried out for each single experimental condition and the results were reported as mean values and standard deviations.

After the completion of the experiment, the number of surviving microorganisms was determined according to the total count in Petrifilm ${ }^{\mathrm{TM}}$ plates selective for E. coli. The effects of pressure were evaluated by means of the experimental design presented in Tables 1 and 2. All results were performed in triplicate and analysed using Statistica ${ }^{\circledR} 7.0$ (Statsoft Inc., Tulsa, OK, USA), considering a significance level of $95 \%(\mathrm{p}<0.05)$. 


\subsection{Optical microscopy}

A histochemistry test was performed using the reactive Steinmetz according to the methodology proposed by Costa (1982). The photomicrographs of the structures were performed with microscope LEICA DM2500. The colouring was made with the use of dye astra blue, as proposed by Maácz and Vágás (1961); colorant aggregation that occurs in the intermicellar spaces of the cellulose, thus highlighting the primary cell walls. The material was exposed to the dye for 5 minutes and followed by wash in distilled water. The images were recorded in digital photography format.

\section{Results and Discussion}

The pumpkin puree sterilized ( $\mathrm{S}$ puree and S puree + HPCD) has lower pH value comparing with non-sterilized samples (In natura, Puree and HPCD puree), and showed no significant difference between them, similar behaviour to the unsterile pumpkin puree (Puree and HPCD puree). The exception was with the fruit in natura, which has higher $\mathrm{pH}$ and significant difference between all $(\mathrm{p}<0.05)$ (Table 1).

Garcia-Gonzalez et al. (2009) argue that the main factor determining bacterial susceptibility to HPCD treatment might be related to the acid resistance of the microorganisms, because a key factor in the inactivation mechanism seems to be the concentration of $\mathrm{CO}_{2}$ (and hence the extracellular $\mathrm{pH}$ ) in the water-phase of the food.

Dissolved $\mathrm{CO}_{2}$ can easily diffuse into the bacterial cell due to increased membrane permeability and accumulates in the cytoplasm, decreasing the internal pH. HPCD with acidification increases bacterial efficacy of treatments. However, it should be taken into account that different constituents in suspending media could also influence the inactivation (Zhou et al., 2014).

To the titratable acidity (TA) results all samples presented significant differences $(\mathrm{p}<0.05)$ among them and the higher value of TA was sterilized puree (S puree) $\left(1.24 \pm 0.001 \% \mathrm{NaOH} 1 \mathrm{~mol} \mathrm{~L}^{-1}\right)$. The sterilized pumpkin puree after HPCD (S puree + HPCD) was the second higher value, indicating that the sterilization process influenced the results of this parameter, as well as its $\mathrm{pH}$ value. Carbonic acid derived from $\mathrm{CO}_{2}$ dissolving into the puree induced the increase of TA and also attributed to more $\mathrm{CO}_{2}$ dissolving.

About the TSS, the only sample that differed statistically $(\mathrm{p}<0.05)$ was the sterilized puree after HPCD (S puree + HPCD - $6.93 \pm 0.12^{\circ}$ Brix).

Zhou et al. (2014) showed no difference in TSS before $\left(8.9 \pm 0.01{ }^{\circ}\right.$ Brix $)$ and after HHP $\left(8.9 \pm 0.06{ }^{\circ}\right.$ Brix $)$ in pumpkin (Cucurbita maxima Duch.) with 5500 bar - $550 \mathrm{MPa} / 10 \mathrm{~min}$ of treatment and during storage this value keeps constant.

The process increased the TRS in pumpkin puree comparing to its natural form. HPCD and sterilization did not affect

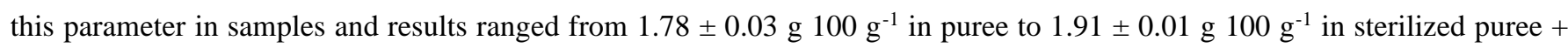

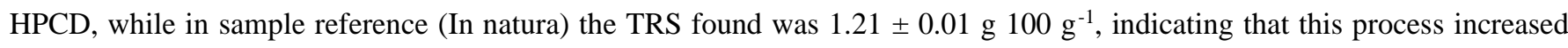
the concentration of reduce sugars in the sample. This increase in TRS can be related to degradation of starch and subsequent conversion into sugar, as it can be observed in optical microscopic, data shown further. 
Table 1. Characterization of raw material and pumpkin puree as to $\mathrm{pH}$, total soluble solids (SST), titratable acidity (TA), total reducing sugars (TRS), total carotenoids and moisture.

\begin{tabular}{|c|c|c|c|c|c|c|}
\hline & pH & $\begin{array}{c}\text { SST } \\
\left({ }^{\circ} \text { Brix) }\right.\end{array}$ & $\begin{array}{c}\mathrm{TA} \\
(\% \mathrm{NaOH} \\
\left.1 \mathrm{~mol} \mathrm{~L}^{-1}\right)\end{array}$ & $\begin{array}{c}\text { TRS } \\
\left(\mathrm{g} 100 \mathrm{~g}^{-1}\right)\end{array}$ & $\begin{array}{c}\text { Total } \\
\text { carotenoids } \\
\left(\mu \mathrm{g} \mathrm{g}^{-1}\right)\end{array}$ & $\begin{array}{l}\text { Moisture } \\
(\text { g 100g-1) }\end{array}$ \\
\hline In natura & $6.50 \pm 0.01^{\mathrm{a}}$ & $6.07 \pm 0.12^{b}$ & $0.51 \pm 0.004^{\mathrm{e}}$ & $1.21 \pm 0.01^{\mathrm{d}}$ & $63.21 \pm 1.65^{c}$ & $92.48 \pm 0.16^{\mathrm{a}}$ \\
\hline Puree & $6.35 \pm 0.01^{\mathrm{b}}$ & $6.20 \pm 0.00^{\mathrm{b}}$ & $0.71 \pm 0.002^{\mathrm{d}}$ & $1.78 \pm 0.003^{c}$ & $59.97 \pm 0.62^{c}$ & $92.50 \pm 0.11^{\mathrm{a}}$ \\
\hline S puree & $5.75 \pm 0.07^{\mathrm{c}}$ & $6.20 \pm 0.00^{\mathrm{b}}$ & $1.24 \pm 0.001^{\mathrm{a}}$ & $1.84 \pm 0.02^{\mathrm{b}}$ & $60.82 \pm 0.54^{\mathrm{c}}$ & $92.07 \pm 0.07^{\mathrm{b}}$ \\
\hline $\begin{array}{l}\text { HPCD } \\
\text { puree }\end{array}$ & $6.33 \pm 0.01^{b}$ & $6.27 \pm 0.12^{b}$ & $0.75 \pm 0.000^{c}$ & $1.81 \pm 0.003^{\mathrm{bc}}$ & $82.58 \pm 0.29^{a}$ & $91.61 \pm 0.01^{\mathrm{c}}$ \\
\hline $\begin{array}{l}\text { S puree + } \\
\text { HPCD }\end{array}$ & $5.65 \pm 0.03^{c}$ & $6.93 \pm 0.12^{\mathrm{a}}$ & $1.04 \pm 0.014^{\mathrm{b}}$ & $1.91 \pm 0.01^{\mathrm{a}}$ & $76.82 \pm 1.06^{b}$ & $91.99 \pm 0.01^{b}$ \\
\hline
\end{tabular}

S puree: sterilized puree; HPCD: high pressure carbon dioxide;

Values in the same column with different superscript letters are significantly different $(\mathrm{p}<0.05)$ according to Tukey test. Source: Authors.

Slight increase but significant $(\mathrm{p}<0.05)$ variations in total carotenoids after HPCD (HPCD puree and S puree + HPCD) were observed. The non-sterilized pumpkin puree after HPCD (HPCD puree) showed higher value of total carotenoids $\left(82.58 \pm 0.29 \mu \mathrm{g} \mathrm{g}^{-1}\right)$. These findings are particularly interesting as carotenoids have positive effects on human health, and their presence gives an important contribution to the general acceptance of pumpkin puree treated by HPCD, which did not show detrimental effects on carotenoid levels.

Barba et al. (2015) reported that HP treatment can increase extractable carotenoid amount in plant-based products. In general, authors who evaluated the feasibility of HP treatment to increase the amount of extractable carotenoids in beverages based in fruit and vegetables obtained good results. They observed that the extractability of carotenoids in samples was clearly influenced by HP treatment conditions, but further investigations are necessary to establish the feasibility of extraction of carotenoids (Sanchez-Moreno et al., 2005; Plaza et al., 2006).

Kebede et al. (2014) reported that it is noteworthy that both carotenoid and unsaturated fatty acid degradation can be linked to oxidative reaction, which seem to be favoured by high pressure. This is in line with reports in which oxidative chemical reaction were enhanced under increased pressure.

The moisture decreases when puree was sterilized and submitted to a HPCD (S puree + HPCD). A significant difference between all samples was to HPCD puree, i. e., non-sterilized puree. These results suggest the HPCD induces to a loss of moisture, especially in the depressurization step, but not significantly enough to dry the sample.

A screening procedure was initially performed to determine which variables and levels of those variables resulted in the best experimental conditions for inactivation of $E$. coli in pumpkin puree. This behaviour is in accordance with Silva et al. (2013), who also reported the importance of pressure cycles and depressurization rate in the inactivation of E. coli. The best experimental condition chosen to perform in kinetics is 275 bar $(27.5 \mathrm{MPa})$ and ratio 1:1, which obtained a reduction of 2.04 log cycles in the sample.

Soares et al. (2013) reported that the increased of $\mathrm{CO}_{2}$ proportion in the system favours the microorganism inactivation. They cited Erkmen (2001a; 2001b), who explains that the increase of $\mathrm{CO}_{2}$ concentration enables a better diffusion 
through the cell membrane, facilitating the cell burst during depressurization, when the expansion of $\mathrm{CO}_{2}$ occurs, leading to improved inactivation efficiency.

In Figure 1 it can be observed a tendency to a greater reduction of microorganisms as the process time increases. Each point of process was under the same conditions (pressure and temperature) during the whole HPCD process. The inactivation of E. coli with supercritical carbon dioxide follow a first-order kinetics, as it is confirmed by the good agreement with experimental data.

The value of inactivation constant depends on the type of microorganism, medium, pressure and temperature. The correlation coefficient, $R^{2}$, was 0.90 in this work, similar to that obtained by Silva et al. (2013). These authors reported that the inactivation constant increases with pressure, indicating that high pressures accelerate the rate of inactivation while the decimal reduction time $(D)$ decreases with increasing pressure, as expected. In this work, $k$ at 275 bar (27.5 MPa) was $0.018 \mathrm{~min}^{-1}$ and $D$ was $125.53 \mathrm{~min}$.

The $k$ value was very lower and, consequently, $D$ value was much higher than that found by Silva et al. (2013). These values can be explained by the difference among the matrixes used for HPCD. For the chemical complexity of pumpkin puree, perhaps only elevated pressure is not enough to reach a high rate of inactivation and thus it is necessary to study the variation of other parameters. The maximum reduction achieved by HPCD was $3.186 \pm 0.077 \log$ cycles in $8 \mathrm{~h}$ of process.

Figure 1. Inactivation of E. coli in pumpkin puree with HPCD at 275 bar of pressure and ratio ( $\mathrm{v} \mathrm{CO}_{\mathrm{CO}} / \mathrm{v}$ pumpkin puree $) 1: 1$ as a function of time ranged of $1-8$ hours.

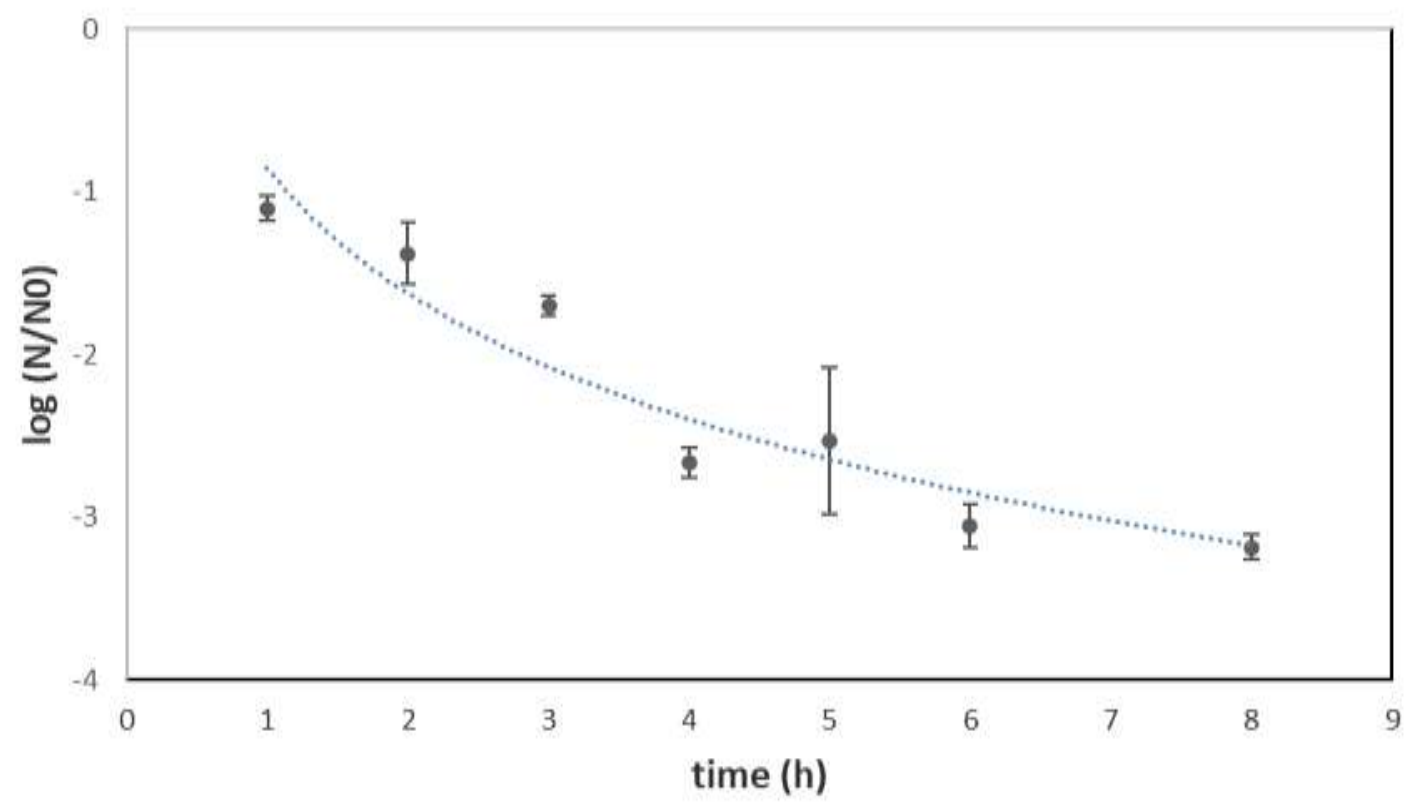

Source: Authors.

The E. coli count decreases as the exposure time increases, but does not reach the total inactivation. This behaviour is in accordance with several authors (Spilimbergo et al., 2003; Silva et al., 2013; Soares et al., 2013). The factors involved in HPCD inactivation are: pressure level, acidification, extraction of cell substances and dysfunctions in membrane permeability (Ortuño et al., 2012).

In accordance with these results, it can be deduced that the pH-lowering effect is one of the causes of microbial inactivation by HPCD (Erkmen, 2001a;2001b; Ortuño et al., 2012). The dissolution of $\mathrm{CO}_{2}$ in the suspension, which results in 
the formation of carbonic acid, can cause a shift in the equilibrium in the direction of generating more hydride ions, since carbonic acid is dissociated to be a hydrogen carbonate and hydride ion (Ortuño et al., 2012). It has also been suggested that $\mathrm{CO}_{2}$ at high pressures could extract vital constituents, including phospholipids and hydrophobic compounds, from cell membranes, which would cause microbial inactivation with the rupture of cell walls (Erkmen, 2001a;2001b). Garcia-Gonzalez et al. (2010) concluded that the role of the $\mathrm{pH}$ decrease of the suspending medium in HPCD inactivation should not be neglected due to its contribution to cause conformational changes in DNA.

The penetration of $\mathrm{CO}_{2}$ through the microbial cell can be the controlling step in inactivation, and the extraction of intracellular contents was a possible inactivation mechanism. Protein denaturation, enzyme inactivation and lipid phase change can perturb the cell morphology, genetic mechanisms and biochemical reactions (Garcia-Gonzalez et al., 2007; Erkmen, 2001a;2001b).

Besides the effect of pressure and $\mathrm{CO}_{2}$ concentration, several studies suggested that elevated temperatures also improved the killing effect of $\mathrm{CO}_{2}$ on microorganisms (Spilimbergo et al., 2003, Erkmen, 2001a;2001b; Yuk et al., 2010).

Insufficient microbial reduction may be related to the increase of TSS and TRS. The data indicate that there was a higher availability of nutrients for E. coli. It is noticed that physicochemical changes can be better correlated with the resistance/sensitivity of microorganisms in which $\mathrm{pH}$ and acidity help in reducing the count, but it is not enough by the availability of nutrients that the process led to.

The initial numbers of $E$. coli may also affect the results. When the initial count is higher, it could be attributed to the clumping of cells as a result of the increased of hydrophobicity during the process. The rate of formation of clumps was proportional to the initial numbers. In addition, some studies have shown that $E$. coli is able to release some protective substances when in high density by quorum-sensing, what may have occurred in this work (Bai \& Rai, 2011).

Figures 2, 3 and 4 show the optical microscopy with around 400 times greater $(400 \times)$ of the pumpkin as raw material parenchyma cells with intact amyloplasts (Figure 2); pressurized pumpkin puree (Figure 3): small deformations in the walls (A) and disruption of the starch granules (B); pumpkin puree immediately after cooking (Figure 4) and the sterilized pumpkin puree (Figure 5).

Any significant histological changes in pumpkin cells were observed. Compared to the pumpkin in natura (raw material) (Figure 2), it appears that the treatment preserved the cellular structure and cell wall integrity. The mesocarp of pumpkin in natura is composed by thickened cells with few small intercellular spaces where middle cells are thin-walled and cytoplasm have an abundant quantity of starch inclusions. After cooking, the parenchyma cells became more separated presenting wide intercellular spaces. Paciulli et al. (2015) and Sila et al. (2006) observed that cells separation did not involve any visible change in cell walls. They hypothesized that this was due to a breakage of chemical bonds between the pectic components of the middle lamellae of cells and/or to a hydrolysis of some other components of the cell wall such as pectin, hemicelluloses and cellulose. In this case of this study, the separation of cells after cooking step might be ascribed to a decrease of the strength of cell-cell interactions in the middle mesocarp. 
Figure 2. Parenchyma cells with intact amyloplasts in pumpkin raw material, 400× (A), (B), (C), (D), € and (F).
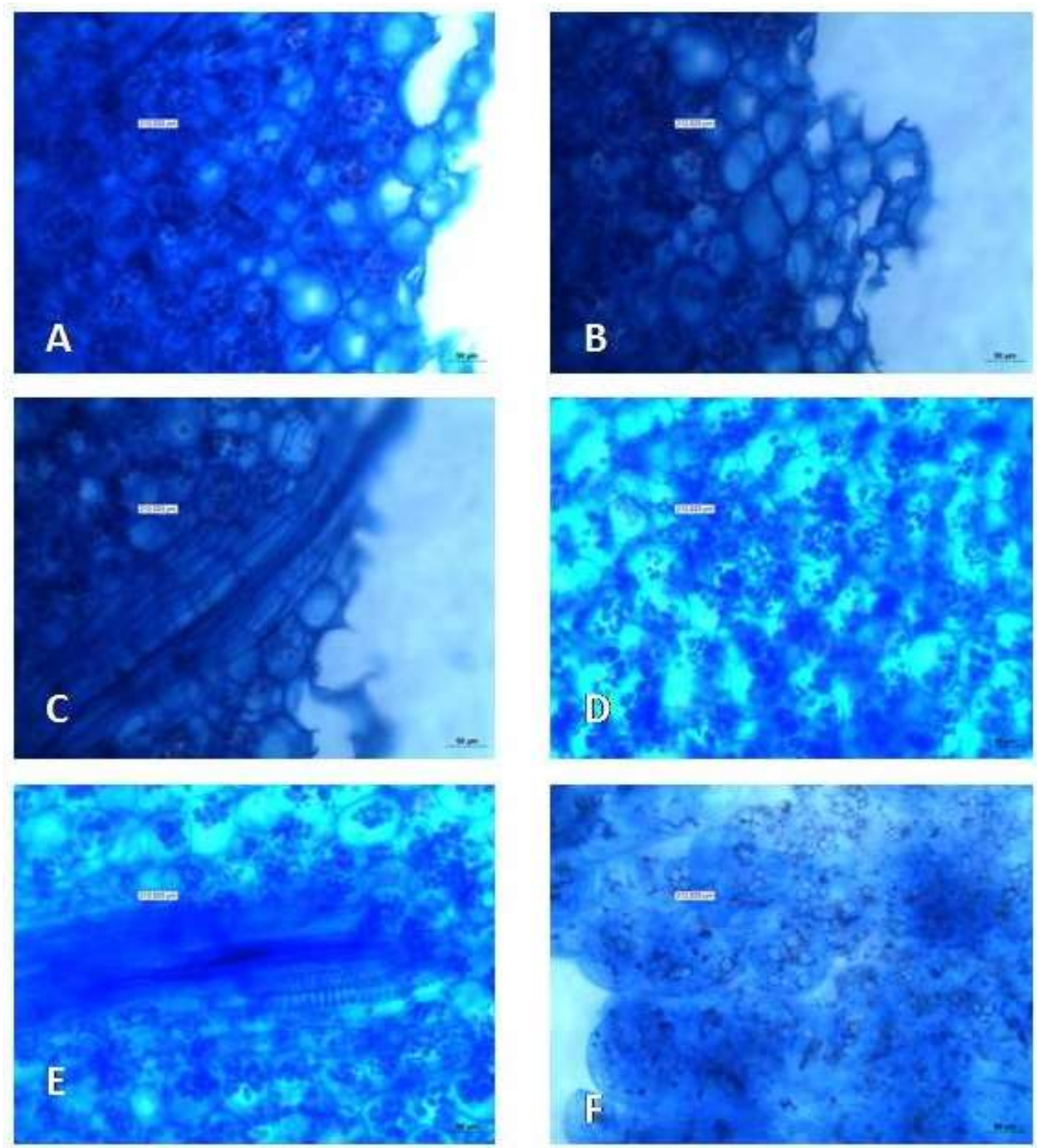

Source: Authors.

Processing only damaged the starch, what was expected because it is a cooked product, at first (Figures 3, 4, 5). Samples subjected to high pressure just showed few discontinuities in the walls in comparison to raw ones, but nothing about breaking them (Fig. 3) while subjected to sterilization temperature $\left(121^{\circ} \mathrm{C}\right)$ showed (Fig. 5) cells that appeared turgid, not uniform, with evident starch inclusions. According Alvarez et al. (2015), the degree of gelatinization starch depends on the intensity of the pressure and the treatment time. The intercellular spaces appeared similar to raw material. Immersed in Figure 3 , sieve tube element is visible. 
Research, Society and Development, v. 10, n. 4, e6510413853, 2021

(CC BY 4.0) | ISSN 2525-3409 | DOI: http://dx.doi.org/10.33448/rsd-v10i4.13853

Figure 3. Pressurized pumpkin puree: small deformations in the walls (A) and disruption of the starch granules (B), 400×.
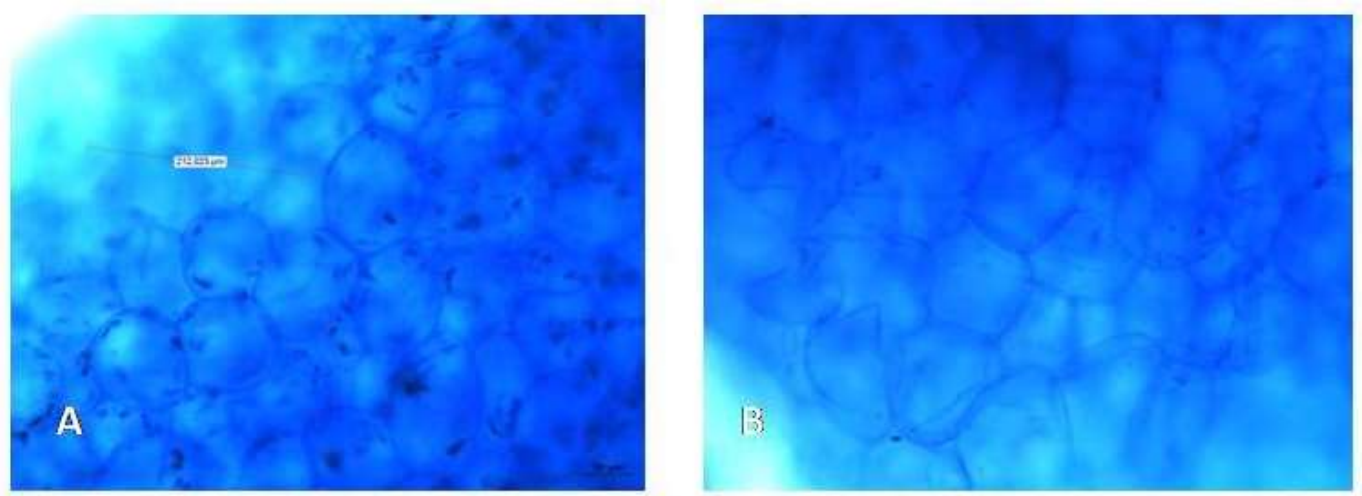

Source: Authors.

Figure 4. Pumpkin puree immediately after cooking. arrow in (c): sieve tube element (phloem), $400 \times$. (A), (B), (C), (D) and (E).
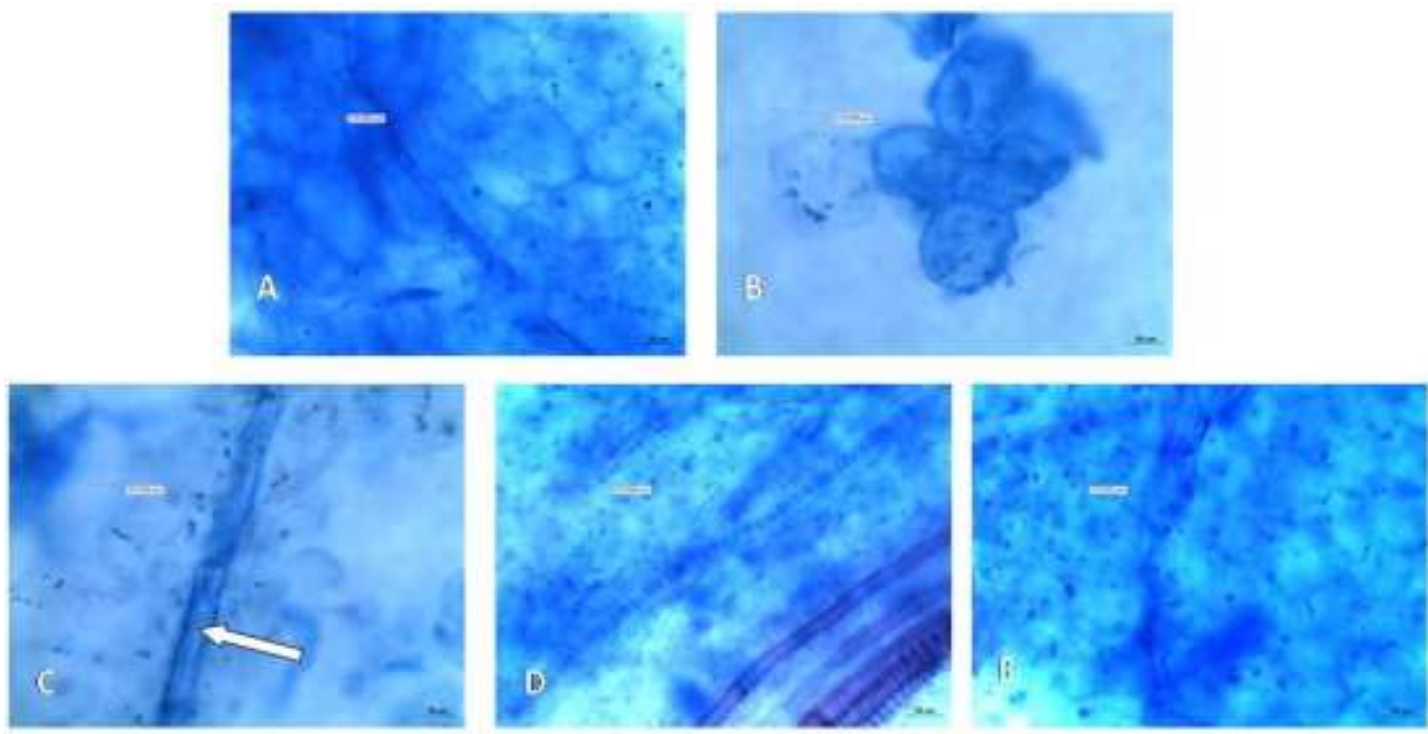

Source: Authors.

Figure 5. Sterilized pumpkin puree, $400 \times$. (A) and (B).
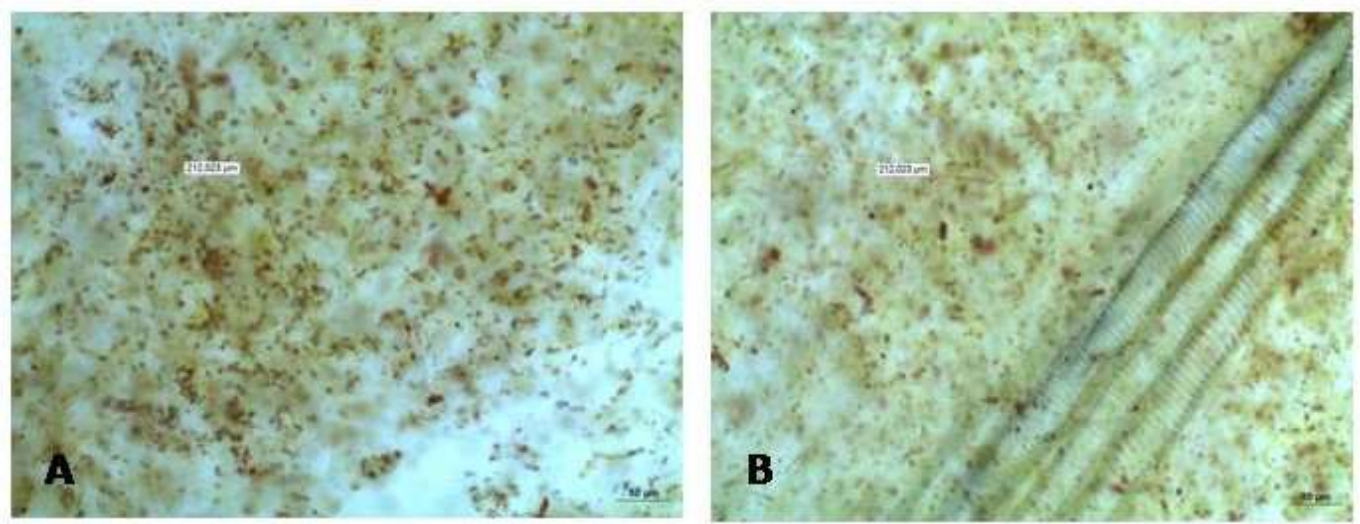

Source: Authors. 
No literature data showing the changes by a treatment at high pressure in puree in general was found, except in pressure above $100 \mathrm{MPa}$ (1000 bar) (Paciulli et al., 2019). The majority of microscopic analysis aimed to observe the damage in microbiological cells and not damages in the environment in which they are inserted. These results lead us to believe that processing by HPCD within a target microbiological safety preserves most of the integrity of the product which is being subjected to such process.

\section{Conclusion}

The experimental results showed that treatment by HPCD in the conditions tested needs to be improved, because it proved to be limited as to this innovative technique for non-heat treatment of pumpkin puree. Even though the processes assure physicochemical characteristics, above all, the microbiological safety of the treated samples was not enough to this product. These results indicate that the exploitation on industrial scale or continuous mode of such a technique must be limited to foodstuff with microbiological safety and further experiments are needed to investigate these issues in a deeper way in order to optimize the process aiming at a practical exploitation of HPCD in this field.

\section{Acknowledgments}

Authors are grateful to the CNPq (Conselho Nacional de Desenvolvimento Científico e Tecnológico, Brazil) for their financial support and to CAPES (Coordenação de Aperfeiçoamento de Pessoal de Nível Superior), by the scholarships.

\section{References}

Alvarez, M. D., Fuentes, R., \& Canet, W. (2015). Effects of pressure, temperature, treatment time, and storage on rheological, textural, and structural properties of heat-induced chickpea gels. Foods, 4, 80-114. https://doi.org/10.3390/foods4020080

Bai, A. J., \& Rai, V. R. (2011). Bacterial Quorum Sensing and Food Industry. Comprehensive Reviews in Food Science and Food Safety, 10, 183-193. https://doi.org/10.1111/j.1541-4337.2011.00150.x

Barba, F. J., Terefe, N. S., Buckow, R., Knorr, D., \& Orlien, V. (2015). New opportunities and perspectives of high-pressure treatment to improve health and safety attributes of foods. A review. Food Research International, 77, 725-742. https://doi.org/10.1016/j.foodres.2015.05.015

Costa AF. (1982). Farmacognosia: Farmacognosia Experimental. (2ª ed.). Fundação Calouste Gulbenkian.

Erkmen, O. (2001a). Mathematical modelling of Escherichia coli inactivation under high pressure carbon dioxide. Journal of Bioscience and Bioengineering, 92, 39-43. https://doi.org/10.1016/S1389-1723(01)80196-1

Erkmen, O. (2001b). Effects of high-pressure carbon dioxide on Escherichia coli in nutrient broth and milk. International Journal of Food Microbiology, 65, 131-135. https://doi.org/10.1016/S0168-1605(00)00499-2

Ferrentino, G., \& Spilimbergo, S. (2011). High pressure carbon dioxide pressurization of solid foods: Current knowledge and future outlooks. Trends in Food Science and Technology, 22, 427-441. https://doi.org/10.1016/j.tifs.2011.04.009

Furukawa, S., Watanabe, T., Koyama, T., Hirata, J., Narisawa, N., \& Ogihara, H. (2009). Inactivation of food poisoning bacteria and Geobacillus stearothermophilus spores by high pressure carbon dioxide treatment. Food Control, 20, 53-55. https://doi.org/10.1016/j.foodcont.2008.02.002

Garcia-Gonzalez, L., Geeraerd, A. H., Elst, K., Van Ginneken, L., Van Impe, J. F., \& Devlieghere, F. (2009). Influence of type of microorganism, food ingredients and food properties on high-pressure carbon dioxide inactivation of microorganisms. International Journal of Food Microbiology, $129,253-263$. https://doi.org/10.1016/j.ijfoodmicro.2008.12.005

Garcia-Gonzalez, L., Geeraerd, A. H., Mast, J., Briers, Y., Elst, K., Van Ginneken, L., Van Impe, J. F., \& Devlieghere, F. (2010). Membrane permeabilization and cellular death of Escherichia coli, Listeria monocytogenes and Saccharomyces cerevisiae as induced by high pressure carbon dioxide treatment. Food Microbiology, 27, 541-549. https://doi.org/10.1016/j.fm.2009.12.004

Garcia-Gonzalez, L., Geeraerd, A. H., Spilimbergo, S., Elst, K., Van Ginneken, L., Debevere, J., Van Impe, J. F., \& Devlieghere, F. (2007). High pressure carbon dioxide inactivation of microorganisms in foods: The past, the present and the future. International Journal of Food Microbiology, 117, 1-28. https://doi.org/10.1016/j.ijfoodmicro.2007.02.018

Jay, J. M. (2005). Food Microbiology. (6a ed.). Artmed. 
Kebede, B. T., Grauwet, T., Mutsokoti, L., Palmers, S., Vervoort, L., Hendrickx, M., \& Loey, A. V. (2014). Comparing the impact of high-pressure high temperature and thermal sterilization on the volatile fingerprint of onion, potato, pumpkin and red beet. Food Research International, 56, 218-225. https://doi.org/10.1016/j.foodres.2013.12.034

Kimura, M., Kobori, C. N., Rodriguez-Amaya, D. B., \& Nestel, P. (2007). Screening and HPLC methods for carotenoids in sweetpotato, cassava and maize for plant breeding trials. Food Chemistry, 100, 1734-1746. https://doi.org/10.1016/j.foodchem.2005.10.020

Kimura, M., \& Rodriguez-Amaya, D. B. (2002). A scheme for obtaining standards and HPLC quantification of leafy vegetable carotenoids. Food Chemistry, 78, 389-398.

Maácz, G. L., \& Vágás, E. (1961). A new method for staining of cellulose and lignified cells-walls. Mikroskopie, $16,40-43$.

Miller, G. L. (1959). Use of dinitrosalicylic acid reagent for determination of reducing sugar. Analitical Chemistry, 31, 426-428.

Plaza, L., Sanchez-Moreno, C., De Ancos, B., \& Cano, M. P. (2006). Carotenoid content and antioxidant capacity of Mediterranean vegetable soup (gazpacho) treated by high-pressure/temperature during refrigerated storage. European Food Research and Technology, 223, 210-215. https://doi.org/10.1007/s00217$005-0174-\mathrm{z}$

Ortuño, C., Martínez-Pastor, M. T., Mulet, A., \& Benedito, J. (2012). Supercritical carbon dioxide inactivation of Escherichia coli and Saccharomyces cerevisiae in different growth stages. Journal of Supercritical Fluids, 63, 8-15. https://doi.org/10.1016/j.supflu.2011.12.022

Paciulli, M., Ganino, T., Pellegrini, N., Rinaldi, M., Zaupa, M., Fabbri, A., \& Chiavaro, E. (2015). Impact of the industrial freezing process on selected vegetables - Part I. Structure, texture and antioxidant capacity. Food Research International, 74, 329-337. https://doi.org/10.1016/j.foodres.2014.04.019

Paciulli, M., Rinaldi, M., Rodolfi, M., Ganino, T., Morbarigazzi, M., \& Chiavaro, E. (2019). Effects of high hydrostatic pressure on physico-chemical and structural properties of two pumpkin species. Food Chemistry, 274, 281-290. https://doi.org/10.1016/j.foodchem.2018.09.021

Reid, R. C., Prausnitz, J. M., \& Poling, B. E. (1985). The properties of gases and liquids. Fourth (ed). McGraw-Hill Book Company.

Sanchez-Moreno, C., Plaza, L., Elez-Martinez, P., De Ancos, B., Martin-Belloso, O., \& Cano, M. P. (2005). Impact of high pressure and pulsed electric fields on bioactive compounds and antioxidant activity of orange juice in comparison with traditional thermal processing. Journal of Agricultural and Food Chemistry, 53, 4403-4409. https://doi.org/10.1021/jf048839b

Sátiro, L. de S., Costa, F. B. da, Nascimento, A. M. do, Silva, J. L. da, Nobre, M. A. F., Araujo, C. R. de, Gadelha, T. M., \& Lira, R. P. de (2020). Avaliação da qualidade físico-química da abóbora brasileirinha (Cucurbita moschata) minimamente processada. Research, Society and Development, 9(5), e58953202. https://doi.org/10.33448/rsd-v9i5.3202

Sila, D. N., Doungla, E., Smout, C., Van Loey, A., \& Hendrickx, M. (2006). Pectin fraction interconversions: Insight into understanding texture evolution of thermally processed carrots. Journal of Agriculture and Food Chemistry, 54, 8471-8479. https://doi.org/10.1021/jf0613379

Silva, J.M., Rigo, A. A., Dalmolin, I. A., Debien, I., Cansian, R. L., Oliveira, J. V., \& Mazutti MA. (2013). Effect of pressure, depressurization rate and pressure cycling on the inactivation of Escherichia coli by supercritical carbon dioxide. Food Control, 29 , 76-81. https://doi.org/10.1016/j.foodcont.2012.05.068

Soares, D., Lerin, L. A., Cansian, R. L., Oliveira, J. V., \& Mazutti, M. A. (2013). Inactivation of Listeria monocytogenes using supercritical carbon dioxide in a high-pressure variable-volume reactor. Food Control, 31, 514-518. https://doi.org/10.1016/j.foodcont.2012.11.045

Spilimbergo, S., Dehghani, F., Bertucco, A., \& Foster N. (2003). Inactivation of bacteria spores by pulse electric field and high-pressure CO 2 at low temperature. Biotechnology and Bioengineering, 82, 118-125. https://doi.org/10.1002/bit.10554

Yuk, H., Geveke, D. J., \& Zhang, H. Q. (2010). Efficacy of supercritical carbon dioxide for non-thermal inactivation of Escherichia coli K12 in apple cider. International Journal of Food Microbiology, 138, 91-99. https://doi.org/10.1016/j.ijfoodmicro.2009.11.017

Zhou, C., Liu, W., Zhao, J., Yuan, C., Song, Y., Chen, D., Ni, Y., \& Li, Q. (2014). The effect of high hydrostatic pressure on the microbiological quality and physical-chemical characteristics of Pumpkin (Cucurbita maxima Duch.) during refrigerated storage. Innovative Food Science \& Emerging Technologies, 21 , 24-34. https://doi.org/10.1016/j.ifset.2013.11.002 